\title{
AFRICAN STUDIES: THE AMBIGUITY OF OWNERSHIP AND ORIGINALITY
}

\author{
Henning Melber
}

HENNING MELBER is Director Emeritus/Senior Adviser at the Dag Hammarskjöld Foundation in Uppsala, Sweden, and Extraordinary Professor at the Centre for Africa Studies of the University of the Free State in Bloemfontein and the Department of Political Sciences at the University of Pretoria. Email: henning.melber@dhf.uu.se

Arowosegbe's article is a welcome invitation to reconsider African studies by reflecting on the dubious ambiguities of their ownership. While he dismisses Western hegemony, he also demands acknowledgement of the relevance of Western thought to the discipline. The latent tension and challenge to reconcile these demands are underlined by his parallel references to knowledge production in as well as on Africa without a further clarifying distinction.

Arowosegbe dismisses African colleagues in history, philosophy and psychology who have little knowledge of the contributions by European thinkers to these subjects. While this might be the case, his line of argument implies a causal relationship with the presumed ignorance concerning other schools of thought emanating from a European tradition. This raises the question of whether such an exchange requires knowing the other's intellectual history, socialization, scholarly traditions and schools of thought. And, if so, how could an element of reciprocity be secured by empowering non-African scholars by means of adequate exposure to African traditions and thought? ${ }^{1}$

Arowosegbe argues elsewhere (2014: 318) 'that knowledge production within the field of African studies is compromised, crippled and tied to a Eurocentric order that is not only inimical to the construction of an Africa-centred scholarship and endogenous knowledge systems but also detrimental to the developmental needs of the continent'.

\footnotetext{
${ }^{1}$ This implies - for the sake of the argument - that categories such as 'European' and 'African' exist in a clearly identifiable ('pure', so to speak) exchangeable version. This is questionable but cannot be dealt with adequately here (for more on this, see Melber 2009, 2014).
} 
This leads to another dilemma, regarding Arowosegbe's praise of the South African system of higher education. This indeed compares favourably with most other African state policies despite a lot of shortcomings. Noteworthy in particular is its promotion of academic knowledge production by means of a material reward system for published articles in accredited, peer-reviewed journals. While this is a laudable support mechanism, current practices by South African universities reinforce their inherited structural distortions: they consider publishing in Western academic periodicals to be of the highest repute and hence allocate more money for such publications to the individual research budgets of their academic staff. In specific terms, publications in accredited journals are reported annually by institutions of higher learning to the government's Department of Higher Education and Training (DHET) and receive financial rewards according to a list of registered and accredited journals. The University of Pretoria, for example, then allocates a disproportionately higher amount to researchers for publications in what the institution considers to be the more prestigious international journals, notwithstanding the fact that the DHET itself makes no such distinction and allocates the same subsidies to articles in all registered periodicals. As a result of such individual university policies, internationally accredited journals are considered to be the first choice for authors seeking to maximize their research budgets - an invidious vicious circle that reinforces Northern dominance. Many of the 'international' journals (and indeed a wide range of local South African journals) are marketed by fewer than a handful of commercial publishers at relatively high costs for readers, while individual free access to articles is usually very limited. Therefore, knowledge production is encouraged to remain an external domain by the institutions of local higher education by being linked mainly to prestigious forums abroad and not measured against criteria of 'endogenous' knowledge produced and disseminated locally. This perpetuates a distorted world of knowledge production. It also demonstrates that even the best of intentions might have a negative effect. The fact that this debate appears in a periodical published outside Africa (while it addresses issues of African scholarship and universities on the continent) illustrates the point.

In light of such realities, the World Social Science Report 2010 provided sobering evidence that the current 'internationalization' - like its preceding stages - reinforces the dominance of the North. As Ebrima Sall (2010: 44-5) concludes: 'The challenge of autonomy, and of developing interpretative frameworks that are both scientific and universal, and relevant that is, "suitable" for the study of Africa and of the world from the standpoint of Africans 
themselves - is still very real.' His predecessor as Executive Secretary of CODESRIA is just as adamant in advocating a similar dismissal of foreign perspectives imposed upon the continent and its people as an integral part of the 'North-South asymmetries in international knowledge production' (Olukoshi 2007: 17). Meanwhile, a closer investigation of Africabased journals in the social sciences discloses a vast interdisciplinary and multifaceted world of differing discourses representing a wide panorama of locally based and owned reflections. These are not confined to some kind of irredentism unable to add insights to an African as well as a globally (or universally) relevant debate (cf. Krenceyová 2014).

Enter Hamid Dabashi, who criticizes dominant forms of Western knowledge executing the power of definition. As controversial - and maybe even unfair - as some of his polemics might be, he offers a fitting perspective to complement Arowosegbe. Challenging the uncritical admiration and celebrity status of almost exclusively European thinkers who are elevated to the commanding heights of universal philosophy and history, he wonders 'what happens with thinkers who operate outside the European philosophical "pedigree"?' He points to 'a direct and unmitigated structural link between an empire, or an imperial frame of reference, and the presumed universality of a thinker thinking in the bosoms of that empire' (Dabashi 2013). One can look forward to his further challenges (Dabashi 2015). While, predictably, these will not be able to present simple answers to a complex reality, they might offer enough food for thought for further fruitful and stimulating (controversial) exchanges. After all, as Pankaj Mishra (2014) maintains: 'that old spell of universal progress through western ideologies - socialism and capitalism - has been decisively broken', since 'Europe no longer confidently produces, as it did for two centuries, the surplus of global history' (Mishra 2015).

\section{REFERENCES}

Arowosegbe, J. O. (2014) 'African studies and the bias of Eurocentricism', Social Dynamics 40 (2): 308-21.

Dabashi, H. (2013) 'Can non-Europeans think? What happens to thinkers who operate outside the European philosophical “pedigree”?', Al Jazeera, 15 January <http://www.aljazeera.com/indepth/opinion/2013/01/2013114142638797542.html>, accessed 11 February 2015.

Dabashi, H. (2015) Can Non-Europeans Think? London: Zed Books. 
Krenceyová, M. (2014) 'Who is allowed to speak about Africa? A reflection on knowledge, positionality, and authority in Africanist scholarship', Africa Insight 44 (1): 8-22.

Melber, H. (2009) 'The relevance of African studies', Stichproben: Vienna Journal of African Studies 9 (16): 183-200.

Melber, H. (2014) 'What is African in Africa(n) studies? Confronting the (mystifying) power of ideology and identity', Africa Bibliography 2013: vii-xvii.

Mishra, P. (2014) 'The western model is broken', Guardian, 14 October <http://www.theguardian.com/world/2014/oct/14/-sp-western-model-broken-pankaj-mishra>, accessed 16 February 2015.

Mishra, P. (2015) 'After the Paris attacks: it's time for a new Enlightenment', Guardian, 20 January <http://www.theguardian.com/news/2015/jan/20/-sp-after-paris-its-time-for-newenlightenment>, accessed 16 February 2015.

Olukoshi, A. (2007) 'African scholars and African studies' in H. Melber (ed.), On Africa: scholars and African studies. Contributions in honour of Lennart Wohlgemuth. Uppsala: Nordic Africa Institute.

Sall, E. (2010) 'Council for the Development of Social Science Research in Africa (CODESRIA)' in World Social Science Report 2010: knowledge divides. Paris: United Nations Educational, Scientific and Cultural Organization (UNESCO) and International Social Science Council (ISSC). 